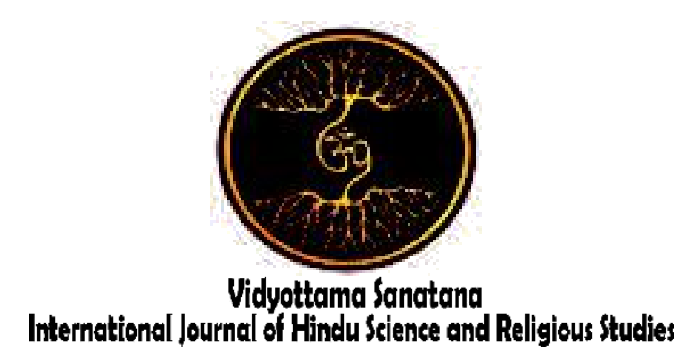

Vol. 3 No. 2 October 2019

\title{
THE EDUCATIONAL VALUE OF HINDU IN TAKING CARE OF PREGNANT WOMAN AND ITS SOCIAL IMPLICATIONS IN THE BALINESE COMMUNITY OF DENPASAR
}

\author{
By: \\ Asthadi Mahendra Bhandesa, Ida Bagus Maha Gandamayu, Ni Luh Adi Satriani \\ The Institute of Health Sciences Bali \\ E-mail : $\underline{\text { bhandesa_asthadi@yahoo.com, bhandesa_asthadi@stikes-bali.ac.id }}$
}

\begin{tabular}{|l|l|l|} 
Received: August 5, 2019 & Accepted: September 11, 2019 & Published: October 31, 2019 \\
\hline
\end{tabular}

\begin{abstract}
Taking care of pregnant women is basically an effort to monitor maternal and child health in order to create a family with quality and live in a healthy environment. The role of family, values and norms and social environment greatly influences the care of pregnant women physically, mentally, spiritually, and socially. This study aims to clarify the educational value of Hindu in taking care of pregnant women and its social implications in the Balinese Hindu community, especially in Denpasar City. The interview, observation and document study techniques were used as data acquisition in this study. Furthermore, the techniques of data analysis were carried out through a data reduction process or selected according to the research objectives. In the process of data analysis, the data were carried out through the research continuously from the beginning to the end of the study. Through a systematic process of tracking and regulating interview transcripts, field notes and other materials, the finding indicated that: 1) the educational value of Hindu in taking care of pregnant women includes; psychological education, then ethics education, theological education, health education; 2) The social implication that applied in the educational value of Hindu in taking care of pregnant women psychologically, mothers would feel comfortable and happy, could support the health of pregnant women and have positive implications for the fetus indirectly in forming good character.
\end{abstract}

Keywords: Value, Hinduism Education, Care, Pregnant Women, Social. 


\section{INTRODUCTION}

The essence of nursing is a process of maintaining health and improving the healing process. The mandate of nursing, the nursing process includes the provision of nursing care biologically, psychologically, socially and spiritually. The provision of safe and comfortable nursing is expected able to improve the health of the community and create a healthy, harmonious and quality environment.

In chapter VI of the Republic of Indonesia Law No. 36 concerning health efforts, Article 46 states that in order to realize the highest degree of health for the community, integrated and comprehensive health efforts are carried out in the form of individual health efforts and public health efforts. Furthermore, Article 49 states that the implementation of health efforts must pay attention to social functions, values, and religious norms, socio-cultural, moral, and professional ethics (Undang-Undang 2009).

Efforts in public health such as improving the level of personal health, education, health, prevention and eradication of infectious diseases, and family planning must also take into account of other knowledge of customs, customs, and the knowledge level of traditional medicine of the local community (Lestaria, Bahar, and Munandar 2017). Good and correct knowledge of the existence of values, norms, beliefs, habits, customs and local wisdom that prevails and develops in the community is also expected to be able to improve health efforts and overall health development, one of which is in taking care of pregnant women.

Taking care for pregnant women and the educational value of Hindu are two entities that are closely related to each other, in which to achieve health status and a generation of kinship. Human education starts from the womb until the elderly so that children have virtue and glory, therefore the education during the womb must be maintained continuously, all forms of harm from the womb, including abortions including despicable acts, virtue, and glory must be maintained until after birth (Agus, 2016). The education from the pregnancy period will give glory and kindness to the family, so it needs to be maintained continuously in the form of family guiding through pregnant women.

In fostering the family, women play a very important role, because women are the main educators in the family. Likewise, the children the first of their touch are the touch of women. Therefore, it is not excessive that the education of children has started since the mother's womb, for example when women are pregnant, it is strictly forbidden to say things that are contrary to religious teachings (Ratini 2015). Giving and planting the education value of Hindu during pregnancy is necessary and should have attention to the women that it is very important, therefore taking care of pregnant women through educational values can improve family health.

The education of Hinduism has a function as a motivator and dynamist who can encourage Hindus to do good and right in achieving life goals, as formulated in the Vedas namely moksartham jagadhitaya ca iti dharma, which means to understand, appreciate, and practice Hinduism, then life, namely spiritual and physical prosperity, the world and the hereafter will be achieved. Therefore, through the Hinduism education will be learned from the most basic or simple things to complex matters, from concrete things to abstract things, and from things that are easy to the difficult one (Team Drafting, 2016).

Awareness of religiousness values in the community shows that the Indonesian people are a religious nation. The religious values are as much as possible reflected in the attitudes and patterns of religious behavior in everyday life. In its function, religion provides guidance on our behavior and actions. In connection with the development of human resources, especially for the younger generation, through the implementation of education can be conveyed and instilled moral messages and valuable values such as honesty, courtesy, 
discipline, hard work, togetherness, sincerity, harmony, the unity, nationalism, idealism, patriotism, environmental wisdom, national integration, harmony between obligations and rights, law enforcement with justice, gender and so on (Team Drafting, 2016).

The perspective of educational philosophy is always directed so that various educational policies and practices are at the noble goal of education itself, in which to make students be smart and have a good personality; people who achieve potential actualization optimally (Rukiyati, 2015). Therefore, the purpose and vision of education is a noble character, of course, this vision of education will be achieved when it starts since the pregnancy period.

Judging from the philosophical, theoretical and empirical background, this research has become very important. This is due to the value of Hinduism education in taking care of pregnant women which has the implications for the health of the fetus, forming a Hindu community that is characterized and cultured, in which children as centers of attention and educational activities, could be started during pregnancy or in the womb. The lack of research that addresses the value of Hinduism education in the care of pregnant women is the main reason for the importance of this study, based on the philosophy and the purpose of education and the value of education during pregnancy is an important part of health and character formation of mothers and babies since pregnancy.

\section{METHODS}

Methodologically, the research was carried out in Denpasar city, in which chosen as the location of the study considering that Denpasar as a heterogeneous and modern society as a place of defense and continuity of Hindu religious values and Balinese culture inspired by Hinduism in the midst of globalization. Another reason, technically, the researchers were in a research location that intensively provides easy access to research subjects. Therefore, it was easier for researchers to observe, observe and interview directly with the speakers. Determination of informants in this study was carried out through several networks, such as information from academics and cultural observers in the research locations selected selectively based on certain criteria. The criteria in the question are individuals who had competence in the field of Hinduism, nursing for pregnant women, community leaders or cultural figures and religious leaders who understand a lot about nursing mothers in a Hinduism perspective. There were three stages in this study. The first was data collection conducted by field observations, researchers, in this case, were not directly involved in it. The object of the study was the care of pregnant women who were much influenced by religious ethics. In addition, the interview method was used, the questions noted and these questions were developed in the field through interview guidelines according to the situation and context encountered during the interview to the depth of the conversation. This method was also supported by document study techniques, namely as an effort to support and complete data from interviews and observations so that this study was clear and complete. Because the object of this study relates to humans, culture, and activities of a society, the application of document studies was seen as very important. Data analysis method was carried out by data analysis techniques proposed by Miles and Huberman in which included three concurrent activities, namely 1) data reduction, 2) data presentation and 3) conclusion (verification) (Basrowi 2008, Suwandi 2008). In the process of data analysis carried out throughout the research and carried out continuously from the beginning to the end of the study. Through a systematic process of tracking and regulating interview transcripts, field notes and other materials.

\section{RESULTS AND DISCUSSION \\ 3.1 The Education Value of Hindu in Taking Care of Pregnant Women}

The efforts to improve public health could not be separated from the values that 
develop in the community, including the education value of beliefs and religions that were embraced as a unified form of culture in society. Individual health was determined by various factors and the environment. For example, biological factors and behavioral factors. Furthermore, something that not less important was the physical environment and social environment. In addition, individual health was also influenced indirectly by two things, namely access to quality health services and policies and interventions carried out (Swarjana and Bali 2017).

The education of Hinduism was the norms that guide humans to always do good for the achievement of a harmonious life in peace and form a noble human and always perform astiti bhakti to Ida Sang Hyang Widhi Wasa with devotion and sacrifices in accordance with the teachings of Hinduism. Hinduism education is a teaching about moral education which is guided according to the instructions of the teachings of religion as a factor of observation that will be a person's safety. So religious education is nothing but guidance given to someone to show the development of manners in instilling a love for religious teachings and willing to do according to religious teachings (Sudarsana 2017). The guidance contained in these religious teachings was needed in an effort to improve public health.

As a conception, the value is abstract, something that is built and is in the mind, cannot be touched and seen directly with the senses. Values could only be inferred and interpreted from human speech, actions, and material. Speech, deeds, and material are manifestations of value (Marzali 2014).

The education values of Hinduism in taking care of pregnant women could be translated into the values of psychological education, then ethics education, theological education, health education. First psychology education when pregnant women were taught by the whole family not to talk painfully, promote love, all families must protect pregnant mothers so that the mind is comfortable, calm and peaceful. All families had a role in how pregnant women during pregnancy had a feeling of balance, anxiety, indecisiveness so that their psychology was maintained.

Ethics education, in family had the role of providing protection to pregnant women and prohibited from speaking harshly, pregnant women were forbidden to sit at the exit, enter places that are not right, enter a dirty place, enter the grave, eat the rest of the ceremony, come to the place where the person dies, say something harsh, respect for the husband, respect for in-laws and family, has to get closer to God, hold the mind clean, guarding her words, regulating her behavior properly guarded, prohibited from fighting, prohibited talking about the ugliness of others, forbidden to hang out with bad people, forbidden to chat in the neighbors for long, keep the words so as not dirty, diligently make offerings to the ancestors and Ida Sang Hyang Widhi, diligently pray, prohibited from eating rotten food that is tamas also the ones that are rajas, the security of food, think to pray before eats, choose food or cook with a devoted heart, could not eat food given by someone that was not clear, prohibited eating something from stranger.

Theologically it is taught to read stories about divinity, mythology about the gods, taught to listen to hymns, say namasmaranam, do service, read stories of heroism, read scriptures, were taught about five sradha, were taught about human relations with the creator, thus this pregnant woman would be guaranteed health in both physically and mentally, prohibited from staying up late, forbidden to eat foods that are forbidden by religion, staying up late being taught by yoga, given healthy ways of life for pregnant women, taught to care for the baby in the womb well and true, it was not permissible to have sex, during the holy days including at the time of birth because it affects the fetus, it was prohibited from drinking liquor and traveling far alone.

Based on the results of the interview, it was found that the educational values of Hinduism which included in taking care of pregnant women included the prohibition of 
stepping over pregnant women, the prohibition of shocking pregnant women, the prohibition of shadowing pregnant women who were eating, the prohibition of saying and abusive behavior for pregnant women. In addition, in general, other education also prioritizes the health and comfort of pregnant women only delivered in different languages.

There was a relationship between health science and the education value of religion. Health science described the educational value of Hinduism in scientific languages, so that people were more receptive, especially to societies with modern logical of thinking. For example the prohibition of saying and doing rude in which health science was able to be associated with the psychological condition of pregnant women which must be maintained to avoid interference with the mother and fetus.

\subsection{Social Implications for Communities in Denpasar City}

Essentially all educational values of religious synergized with other educational values, all of which complement each other. The educational value of Hindu is conventional while other theories have used the scientific method because these two characteristics enlighten pregnant women. Based on the results of interviews with the appointed resource persons, it was found that everything experienced by pregnant women, according to Hinduism must have an effect on the fetus in the womb when the child was born, the character that born will be like what the mother experienced during pregnancy. Therefore, the innate nature of a mother could affect the innate nature of the baby being born. There was a correlation between the educational value of the Hindu with the psychological mother of the baby. The correlation was when the educational value of Hindu is applied so psychologically the mother will feel comfortable. Psychologically maintained had a good impact on health because some diseases may arise due to the pressure of the mind. Mothers with good psychological conditions will have positive implications for the fetus, such as good brain development, normal physical health, and good character.

The care for pregnancy was maintained and taken care for the health of the mother while pregnant. Maintaining personal hygiene and the environment and adequate rest. Taking care of your breasts regularly during pregnancy, eating nutritious and balanced foods. Caring for pregnant women based on the educational value of Hindu strongly emphasizes the belief that pregnant women have specificity, which is protected by Bhatara so that restrictions that protect the comfort of pregnant women. In addition, to taking care of pregnant women in accordance with Hinduism, it had several special treatments related to the safety of the baby that is conceived.

In addition, the strategy for character building based on the educational value of Hindu focus on the psychology of the mother. Some scientific research proved that a mother who was comfortable and happy psychologically indirectly forms a character who tends to be cheerful and confident. The strategy of character building based on the value of health and nursing education as far as I know also emphasizes the mental state of the mother during pregnancy, so that the character formed was expected to be directly proportional to the condition of the mother. The strategy of character building in infants during the womb had an influence on the birth of the baby and the nature of the baby, therefore, the formation of the character of the baby at the time of the womb was very important, so that the character of the baby was in accordance with the teachings of Hinduism. 


\section{CONCLUSION}

Based on the discussion above, it could be concluded that the educational value of Hindu in taking care of pregnant women had several aspects of value, namely psychological education, then ethics education, theological education, and health education. Furthermore, the social implication was applying the educational value of Hindu in the care of pregnant women psychologically, mothers would feel comfortable and happy, could support the health of pregnant women and had positive implications for the fetus in which indirectly forming good character.

\section{REFERENCES}

Agus S. 2016. Menjaga Kehamilan dan Kelahiran Mewujudkan Keluarga Berkualitas. BKKBN.

Basrowi, Suwandi. 2008. Memahami penelitian kualitatif. Jakarta: Rineka Cipta.

Lestaria, Wa Ode Puji, Hartati Bahar, and Sabril Munandar. 2017. "Peran Bidan dan Dukun dalam Perawatan Kehamilan Ibu Hamil di Wilayah Pesisir Kecamatan Abeli (Studi Kasus) Kota Kendari 2016." Jurnal
Ilmiah Mahasiswa Kesehatan

Masyarakat 1 (4).

Marzali, Amri. 2014. "Pergeseran Orientasi

Nilai Kultural dan Keagamaan di Indonesia (Sebuah Esai dalam Rangka Mengenang Almarhum Prof. Koentjaraningrat)." Antropologi Indonesia.

Ratini, Ni Made. 2015. "Perempuan Dalam Sastra Hindu." Belom Bahadat 5 (1).

Rukiyati, dkk. 2015. Mengenal Filsafat Pendidikan. Fakultas Ilmu Pendidikan: UNY

Sudarsana, I Ketut. 2017. "Peningkatan Mutu Pendidikan Agama Hindu Melalui Efektivitas Pola Interaksi Dalam Pembelajaran Di Sekolah." Prosiding Semaya 2:134-142.

Suwandi, Basrowi. 2008. "Memahami Penelitian Kualitatif." Jakarta: Rineka Cipta.

Swarjana, I Ketut, and STIKES Bali. 2017. Ilmu Kesehatan Masyarakat-Konsep, Strategi dan Praktik: Penerbit Andi.

Tim Penyusun. 2016. Pendidikan Agama Hindu. Direktoral Jenderal Pembelajaran dan Kemahasiswaan Kemenristekdikti RI

Undang-Undang, RI. 2009. "Nomor 36 Tahun 2009." Tentang Kesehatan. 